\title{
Lightning and anthropogenic $\mathrm{NO}_{\mathrm{x}}$ sources over the United States and the western North Atlantic Ocean: Impact on OLR and radiative effects
}

\author{
Yunsoo Choi, ${ }^{1}$ Jinwon Kim, ${ }^{2}$ Annmarie Eldering, ${ }^{1}$ Gregory Osterman, ${ }^{1}$ Yuk L. Yung, ${ }^{3}$ \\ $\mathrm{Yu} \mathrm{Gu},{ }^{2}$ and K. N. Liou ${ }^{2}$ \\ Received 30 May 2009; revised 24 July 2009; accepted 4 August 2009; published 4 September 2009.
}

[1] The migration of enhancements in $\mathrm{NO}_{2}$ concentration, outgoing longwave radiation (OLR), and radiative effects associated with the onset of the North American Monsoon in July 2005 has been investigated using satellite data and the Regional Chemical Transport Model (REAM). The satellite data include the tropospheric $\mathrm{NO}_{2}$ columns, tropospheric $\mathrm{O}_{3}$ profiles, and OLR from OMI, TES and NOAA-16 satellite, respectively, for June and July 2005. The simulated OLR captures the spatial distribution of the remotely sensed OLR fields with relatively small biases $(\leq 5.7 \%)$ and high spatial correlations $(\mathrm{R} \geq 0.88)$. This study reveals that the lightning-generated $\mathrm{NO}_{\mathrm{x}}$ exerts a larger, by up to a factor of three, impact on OLR (up to $0.35 \mathrm{Wm}^{-2}$ ) and radiative effects (up to $0.55 \mathrm{Wm}^{-2}$ ) by enhancing $\mathrm{O}_{3}$ in the upper troposphere than anthropogenic $\mathrm{NO}_{\mathrm{x}}$ that increases $\mathrm{O}_{3}$ in the lower troposphere, despite the fact that the lightning-generated $\mathrm{NO}_{\mathrm{x}}$ and $\mathrm{O}_{3}$ are much smaller than those from the anthropogenic emissions. The radiative effect by lightning-derived upper tropospheric $\mathrm{O}_{3}$ over the convective outflow regions is affected by the changes in lightning frequency. Thus the changes in convection due to global warming may alter the geographical distribution and magnitude of the radiative effect of lightning-derived $\mathrm{O}_{3}$, and this paper is a first step in quantifying the current radiative impact. Citation: Choi, Y., J. Kim, A. Eldering, G. Osterman, Y. L. Yung, Y. Gu, and K. N. Liou (2009), Lightning and anthropogenic $\mathrm{NO}_{\mathrm{x}}$ sources over the United States and the western North Atlantic Ocean: Impact on OLR and radiative effects, Geophys. Res. Lett., 36, L17806, doi:10.1029/2009GL039381.

\section{Introduction}

[2] Nitrogen oxides $\left(\mathrm{NO}_{\mathrm{x}}=\mathrm{NO}+\mathrm{NO}_{2}\right)$ are major ozone $\left(\mathrm{O}_{3}\right)$ precursors produced primarily from fossil fuel combustion, lightning, and soil. Among these, $\mathrm{NO}_{\mathrm{x}}$ from anthropogenic emissions and lightning are the most important sources of $\mathrm{O}_{3}$ in the lower and upper troposphere, respectively, over North America and the North Atlantic Ocean [Ridley et al., 1994; Zhang et al., 2003]. Summertime

\footnotetext{
${ }^{1}$ Jet Propulsion Laboratory, California Institute of Technology, Pasadena, California, USA.

${ }^{2}$ Department of Atmospheric and Oceanic Sciences and Joint Institute for Regional Earth System Science and Engineering, UCLA, Los Angeles, California, USA.

${ }^{3}$ Division of Geological and Planetary Sciences, California Institute of Technology, Pasadena, California, USA.
}

Copyright 2009 by the American Geophysical Union. 0094-8276/09/2009GL039381\$05.00 anthropogenic $\mathrm{NO}_{\mathrm{x}}$ emissions over the eastern US have been decreasing since 1999 due to EPA regulations [Frost et al., 2006]; however, the contribution of the anthropogenic emissions to tropospheric $\mathrm{NO}_{\mathrm{x}}$ remains significantly greater than that from lightning [Hudman et al., 2007]. Consequently, anthropogenic emissions contribute more to the tropospheric $\mathrm{O}_{3}$ over the US than lightning, except in the convective outflow regions over the North Atlantic [Choi et al., 2008b].

[3] Lightning and anthropogenic emissions affect different parts of the troposphere, the upper and lower troposphere respectively [Zhang et al., 2003; Hudman et al., 2009]. This has important implications on the radiative impact (defined here as a change of net shortwave $(<4.0 \mu \mathrm{m})$ and longwave $\left(<2200 \mathrm{~cm}^{-1}\right)$ fluxes at the top of the atmosphere) by these two sources. Mid- and upper tropospheric $\mathrm{O}_{3}$ has a larger radiative forcing efficiency than its lower tropospheric counterpart; for example, an increase in $\mathrm{O}_{3}$ of 10 Dobson units in the upper troposphere $(8-12 \mathrm{~km})$ affects the surface temperature six times more than the same increase in the boundary layer $(0-2 \mathrm{~km})$ [Lacis et al., 1990]. Thus, lightning-derived $\mathrm{O}_{3}$ can have a stronger atmospheric radiative impact than $\mathrm{O}_{3}$ from anthropogenic emissions.

[4] A number of studies have analyzed the impact of lightning and anthropogenic $\mathrm{NO}_{\mathrm{x}}$ emissions (referred to as " $\mathrm{LNO}_{\mathrm{x}}$ " and " $\mathrm{ANO}_{\mathrm{x}}$ ") on the amounts of tropospheric $\mathrm{NO}_{\mathrm{x}}$ and $\mathrm{O}_{3}$ [Zhang et al., 2003; Hudman et al., 2007, 2009; Cooper et al., 2007; Choi et al., 2008a, 2008b]; however, the influence of these sources on the atmospheric radiative impact via $\mathrm{O}_{3}$ production remains largely unknown. Cooper et al. [2007] calculated positive all-sky adjusted radiative forcing at the tropopause above Huntsville, Alabama of $0.50 \mathrm{Wm}^{-2}$. The North American Monsoon (NAM) strongly affects both tropospheric dynamics and chemistry over North America [Ridley et al., 1994] and also the vertical structure of $\mathrm{O}_{3}$ [Zhang et al., 2003; Li et al., 2005; Cooper et al., 2007]. Understanding the impact of changes in tropospheric $\mathrm{O}_{3}$ at different altitudes on the radiation field is an important step towards improved quantification of radiative forcing in climate studies.

[5] This study examines the influence of the $\mathrm{O}_{3}$ generated by $\mathrm{LNO}_{\mathrm{x}}$ and $\mathrm{ANO}_{\mathrm{x}}$ on the summertime OLR and radiative impact over the southeastern US and the North Atlantic. The Regional Chemical Transport Model (REAM) model is used to quantify the tropospheric $\mathrm{NO}_{2}$ and $\mathrm{O}_{3}$ enhancements by $\mathrm{LNO}_{\mathrm{x}}$ and $\mathrm{ANO}_{\mathrm{x}}$ in conjunction with the satellite data from the Ozone Monitoring Instrument (OMI) and Tropospheric Emission Spectrometer (TES). We perform a 
Table 1. $\mathrm{NO}_{\mathrm{x}}$ Emissions Inventory in the Contiguous US for June-July 2005

\begin{tabular}{lcc}
\hline Source Type & June $(\mathrm{Tg} \mathrm{N})$ & July $(\mathrm{Tg} \mathrm{N})$ \\
\hline Fossil fuel & $0.46^{\mathrm{a}}$ & $0.47^{\mathrm{a}}$ \\
Lightning & 0.19 & 0.32 \\
Soils & 0.05 & 0.07 \\
Aircraft & 0.014 & 0.014 \\
Biomass & $0.005^{\mathrm{b}}$ & $0.004^{\mathrm{b}}$ \\
Total & 0.72 & 0.88 \\
\hline
\end{tabular}

${ }^{a}$ The EGU and non-EGU $\mathrm{NO}_{\mathrm{x}}$ emissions from $1999 \mathrm{EPA} \mathrm{NEI}$ are reduced by $50 \%$ over the 23 eastern US (http://www.epa.gov/ttn/naaqs ozone/rto/sip/related.html).

${ }^{\mathrm{b}}$ Biomass burning $\mathrm{NO}_{\mathrm{x}}$ emissions are from the Global Fire Emissions Database (GFED) (http://www.geo.vu.nl/users/gwerf/GFED/data).

control and two sensitivity simulations. The control run includes all $\mathrm{NO}_{\mathrm{x}}$ emissions. The two sensitivity runs remove either $\mathrm{LNO}_{\mathrm{x}}$ or $\mathrm{ANO}_{\mathrm{x}}$ so that the effects of different sources can be extracted by differencing the control run and the corresponding sensitivity run. The simulated OLR is evaluated against observations from the NOAA-16 satellite. The simulation is also used to examine the relative importance of

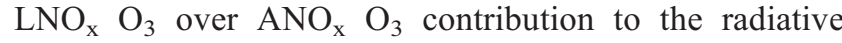
impact before and during the NAM.

\section{Satellite Measurements}

[6] The OMI and TES instruments on board the NASA Aura satellite make nadir measurements at 01:45 and 13:45 local time (LT) with the footprints of $13 \times 24 \mathrm{~km}$ and $5 \times$ $8 \mathrm{~km}$, respectively. The OMI tropospheric $\mathrm{NO}_{2}$ columns [Bucsela et al., 2006] are obtained from the NASA Goddard Earth Sciences Distributed Active Archive Center. Only OMI data with a cloud fraction of $<20 \%$ are used [Choi et al., 2008b]. The TES version $3 \mathrm{O}_{3}$ data are also filtered for quality; only the data that pass the "master" quality flag test [Osterman et al., 2007] are used in the analysis. In order to insure a proper comparison between the REAM results and the TES data, the TES observation operator (referred to as "averaging kernel") is applied to the model profiles [Worden et al., 2007].

[7] The NOAA-16 satellite data are used to locate deep convection and estimate the radiation budget including OLR [Liebmann and Smith, 1996]. The satellite crosses the equator twice a day at 01:50 and 13:50 LT (5 minutes after Aura), and the monthly OLR data are available [Liebmann and Smith, 1996] from the NOAA/ESRL Physical Sciences Division (http://www.cdc.noaa.gov/data/gridded/data. interp_OLR.html).

\section{Model Description}

\subsection{REAM}

[8] The set up for the REAM runs, a horizontal resolution of $70 \mathrm{~km}$ with 23 vertical layers from the surface to $10 \mathrm{hPa}$, is the same as in the work by Choi et al. [2005, 2008a, 2008b]. The 2005 summer GEOS-CHEM (version 7.2) global model simulations [Bey et al., 2001] are used to specify the initial and boundary conditions for trace gases. Emission inventories for the combustion and industrial sources as well as the algorithms for soil and biogenic sources are adopted from GEOS-CHEM, except for $\mathrm{NO}_{\mathrm{x}}$ from anthro- pogenic emissions, biomass burning, and lightning. The $\mathrm{NO}_{\mathrm{x}}$ emissions in the 1999 EPA National Emission Inventory from the Electronic Generation Unit (EGU) and non-EGU point sources in the eastern U.S are reduced by $50 \%$ to account for the recent reduction in anthropogenic emissions [Frost et al., 2006; Hudman et al., 2007]. The anthropogenic $\mathrm{NO}_{\mathrm{x}}$ emissions in Canada and Mexico are from the Sparse Matrix Operator Kernel Emissions (SMOKE) inventory [Kaynak et al., 2008]. Table 1 summarizes the $\mathrm{NO}_{\mathrm{x}}$ emissions inventory for June-July 2005 used in this study. A lightning production rate of 300 moles per flash of NO is used, which is within the currently accepted range of $\mathrm{LNO}_{\mathrm{x}}$ emissions of 30-670 NO moles per flash described by Schumann and Huntrieser [2007]. The Synoz (synthetic ozone; ozone released into the stratosphere at the rate of cross-tropopause ozone flux) method proposed by McLinden et al. [2000] is used in GEOS-Chem [Bey et al., 2001] to simulate cross-tropopause transport of $\mathrm{O}_{3}$.

\subsection{Fu-Liou Radiative Transfer Model}

[9] Atmospheric radiative transfer including the impact of clouds and aerosols is computed using the Fu-Liou scheme [Fu and Liou, 1993; Gu et al., 2003]. The scheme uses the $\delta$-4-stream approximation for the solar flux and the $\delta$-2/4-stream approximation for the infrared flux to achieve a balance between accuracy and computational efficiency. It accounts for the direct radiative effects of 18 aerosol types and the optical properties of liquid- and ice clouds. Details of the scheme are provided in the two references above. The meteorological and chemical fields for calculating atmospheric radiative transfer are prescribed from MM5 and REAM, respectively, except the aerosol fields (sulfate, nitrate, ammonium, carbonaceous aerosols, soil dust, and sea salt) that are obtained from a GEOS-CHEM simulation [Park et al., 2004].

\section{Results and Discussion}

\subsection{OMI Tropospheric $\mathrm{NO}_{2}$ Column}

[10] The simulated $\mathrm{NO}_{2}$ for June-July 2005 agrees reasonably with OMI retrievals (Figure 1) with relatively high spatial correlations $(>0.8)$. The simulation underestimates the observed values by $11.5 \%$ in June but overestimates them by $3.3 \%$ in July over North America and the western Atlantic. Model results indicate that the largest regions of lightning- $\mathrm{NO}_{2}$ generation are over northern Mexico $\left(>2.0 \times 10^{15}\right.$ molecules $\left.\mathrm{cm}^{-2}\right)$ and the southern US $\left(>1.5 \times 10^{15}\right.$ molecules $\left.\mathrm{cm}^{-2}\right)$. Compared to the OMI data, the simulation underestimates $\mathrm{NO}_{2}$ columns over northern California by up to $80 \%$; the simulated $\mathrm{NO}_{2}$ columns are overestimated by less than $20 \%$ in the near coastal region of the Gulf of Mexico and North Atlantic Ocean and by up to $100 \%$ over the oceanic regions. These discrepancies between the OMI data and the simulation are generally comparable to the OMI measurement uncertainties, except over the North Atlantic in July. Compared with GOME [Choi et al., 2008a], the $\mathrm{NO}_{2}$ column from OMI is smaller over the western North Atlantic [Choi et al., 2008b], partially due to the impact of the a priori profiles on the OMI $\mathrm{NO}_{2}$ retrievals [Choi et al., 2008a]. Over the US, the simulated $\mathrm{NO}_{2}$ enhancements due to lightning correspond to $38 \%$ and $58 \%$ of those from anthropogenic emissions in June and July 2005. Note that the lightning-generated $\mathrm{NO}_{2}$ 

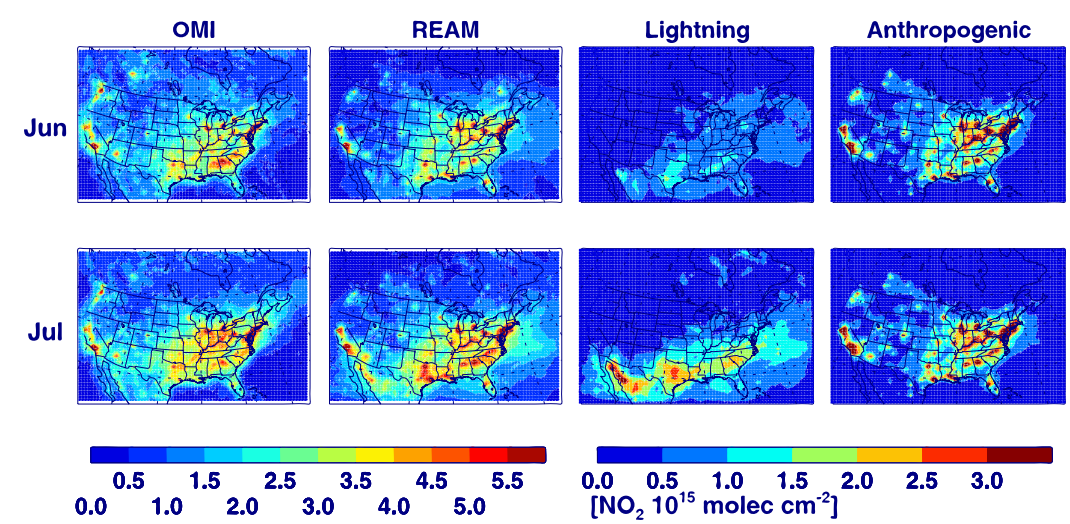

Figure 1. Monthly mean tropospheric $\mathrm{NO}_{2}$ columns over North America and the western Atlantic for June-July 2005 (left to right) from OMI satellite measurements, from REAM simulations, produced by $\mathrm{LNO}_{\mathrm{x}}$, and produced by $\mathrm{ANO}_{\mathrm{x}}$. A different color scale is used for the $\mathrm{LNO}_{\mathrm{x}}$ and $\mathrm{ANO}_{\mathrm{x}}$ plots.

enhancement increases by $57 \%$ in July after the onset of NAM.

\subsection{TES Tropospheric Ozone}

[11] The REAM model results can also be used with TES $\mathrm{O}_{3}$ profiles to investigate the impact of $\mathrm{LNO}_{\mathrm{x}}$ and $\mathrm{ANO}_{\mathrm{x}}$ on the vertical structure of tropospheric $\mathrm{O}_{3}$ (Figure 2). Only the TES retrievals in July 2005 are available. Figure 2 compares the simulated zonal mean tropospheric (surface- $225 \mathrm{hPa}$ ) $\mathrm{O}_{3}$ mixing ratios against the TES retrievals. The most notable discrepancies between the simulated and observed $\mathrm{O}_{3}$ fields occur in the lower troposphere between $32^{\circ} \mathrm{N}$ and $40^{\circ} \mathrm{N}$. In part, the discrepancies are associated with the biases in TES retrievals for the lower troposphere in the northern midlatitudes [Nassar et al., 2008].

[12] The simulation reveals that $\mathrm{LNO}_{\mathrm{x}}$ and $\mathrm{ANO}_{\mathrm{x}}$ enhance $\mathrm{O}_{3}$ in the upper and lower troposphere, respectively (Figure 2). Both the TES retrievals and the simulation show enhanced upper tropospheric $\mathrm{O}_{3}$ to the south of $40^{\circ} \mathrm{N}$ where REAM generates $\mathrm{LNO}_{\mathrm{x}} \mathrm{O}_{3}$ enhancements of 8 16 ppbv. The $\mathrm{O}_{3}$ enhancement of $8-30 \mathrm{ppbv}$ in the lower troposphere between $30^{\circ} \mathrm{N}$ and $45^{\circ} \mathrm{N}$ from $\mathrm{ANO}_{\mathrm{x}}$ is much larger than the upper tropospheric lightning-derived $\mathrm{O}_{3}$ enhancements.

\subsection{Outgoing Longwave Radiation (OLR)}

[13] The OLR reduction by $\mathrm{LNO}_{\mathrm{x}}$ and $\mathrm{ANO}_{\mathrm{x}} \mathrm{O}_{3}$ is investigated using NOAA-16 observations and model data sampled to match the satellite observations (Figure 3). The OLR is estimated for all-sky conditions (including aerosols and clouds). The simulated monthly OLR agrees with the NOAA-16 measurements with relatively small biases of $4.7 \%$ and $5.7 \%$ and high correlation coefficients of 0.88 and 0.89 for June and July 2005, respectively. The model overestimates OLR above the Midwest US and the subtropical western North Atlantic in June 2005. The model

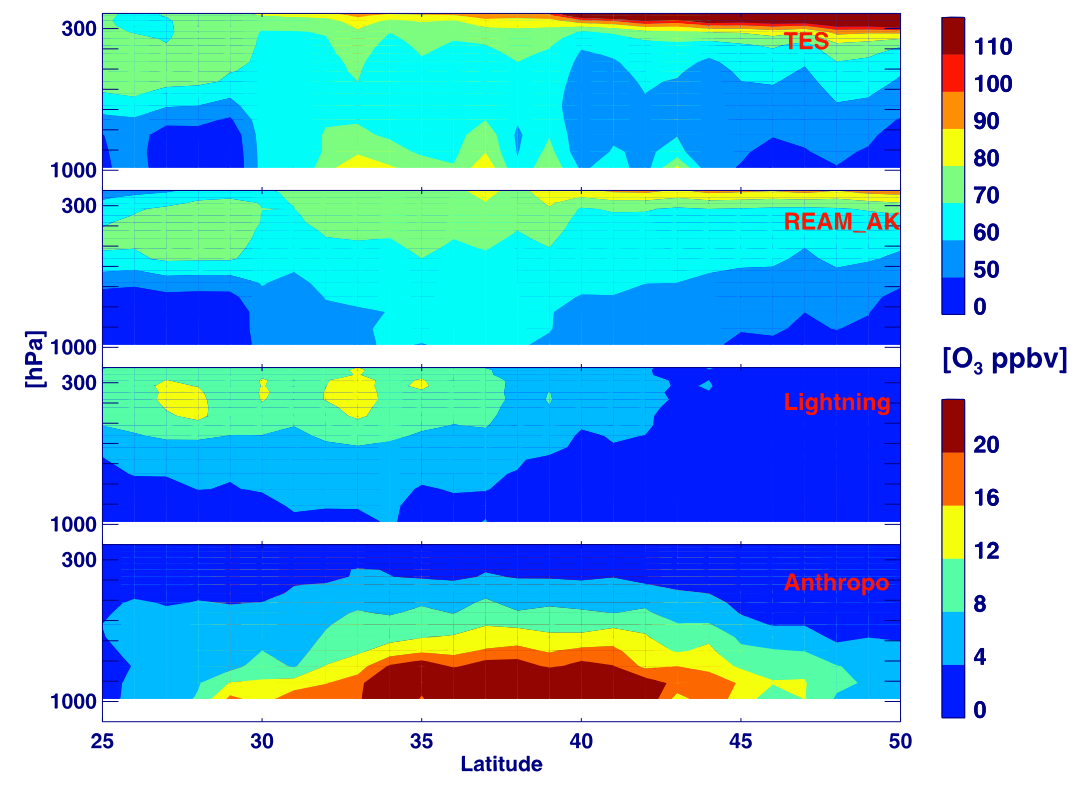

Figure 2. Zonal mean tropospheric $\mathrm{O}_{3}$ mixing ratios over North America and the western North Atlantic (as depicted in Figure 1) for July 2005 (top to bottom) from TES satellite measurements, from REAM with TES averaging kernel applied, produced by $\mathrm{LNO}_{\mathrm{x}}$, and produced by $\mathrm{ANO}_{\mathrm{x}}$. No averaging kernel is applied to the data in the third and fourth panels. 

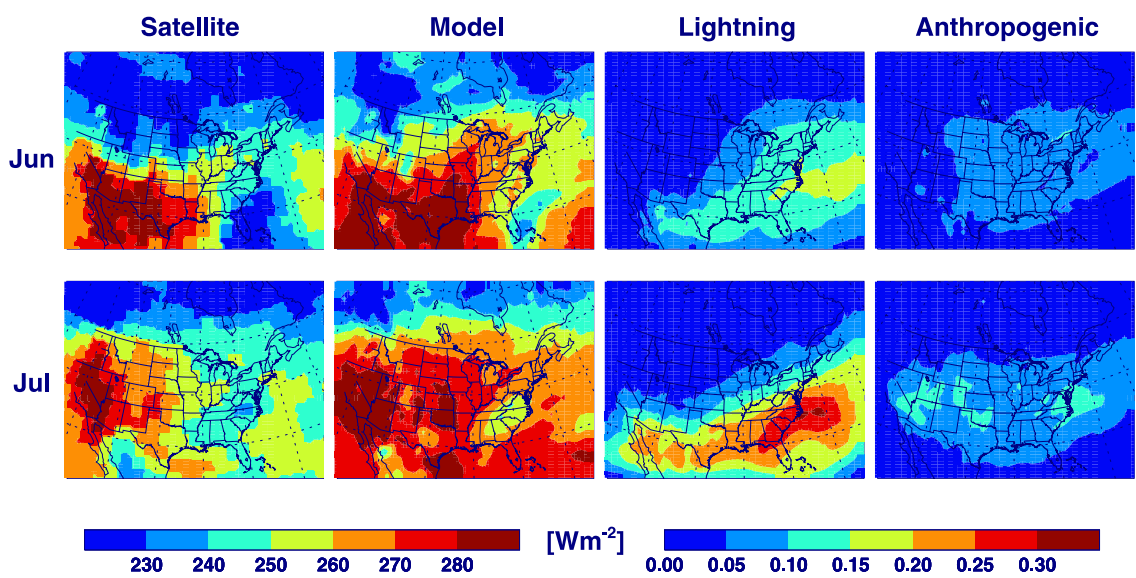

$\left[\mathrm{Wm}^{-2}\right]$

$\begin{array}{lllllll}0.00 & 0.05 & 0.10 & 0.15 & 0.20 & 0.25 & 0.30\end{array}$

Figure 3. Monthly mean OLR over North America and the western Atlantic for June-July 2005 (left to right) from NOAA-16 satellite, from REAM simulation, the amounts reduced by $\mathrm{LNO}_{\mathrm{x}} \mathrm{O}_{3}$, and reduction by $\mathrm{ANO}_{\mathrm{x}} \mathrm{O}_{3}$.

overestimates OLR over most of North America except in the western US and northern Canada in July. Both the simulation and observation show that the peak OLR region over western North America migrates northward from June to July following the onset of the NAM.

[14] The influence of $\mathrm{LNO}_{\mathrm{x}}$ and $\mathrm{ANO}_{\mathrm{x}} \mathrm{O}_{3}$ on OLR during June-July is evident over the convective outflow region. The largest $\mathrm{NO}_{\mathrm{x}}$ production occurs over northwestern Mexico in the simulation (Figure 1); however, the reduction in OLR via $\mathrm{O}_{3}$ production is largest over the outflow regions (Figure 3 ) because of the time needed to form $\mathrm{O}_{3}$ [Choi et al., 2008b]. The $\mathrm{LNO}_{\mathrm{x}} \mathrm{O}_{3}$ reduces OLR by up to $0.35 \mathrm{Wm}^{-2}$ over the outflow region in July; three times more than the peak contribution from $\mathrm{ANO}_{\mathrm{x}}$ $\left(<0.15 \mathrm{Wm}^{-2}\right)$. This result is consistent with previous findings that the sensitivity of radiative impact to tropospheric $\mathrm{O}_{3}$ changes dramatically with increasing altitude, up to the tropopause, due to the increase of the temperature
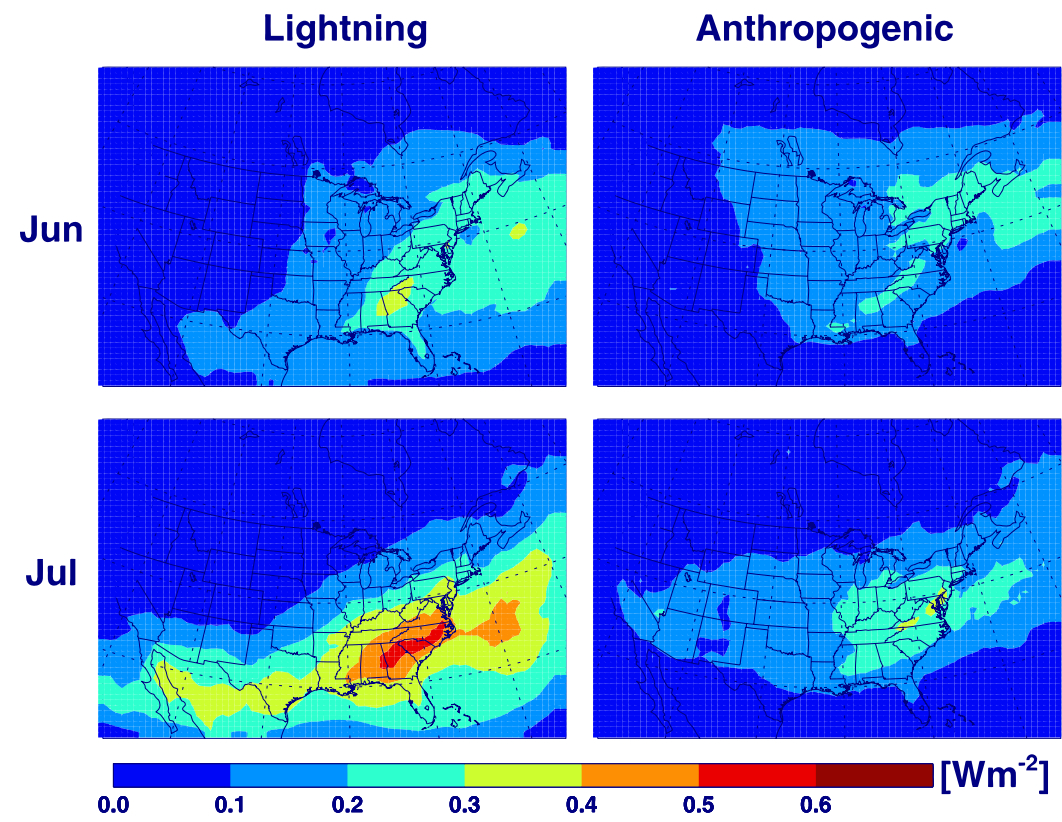

Figure 4. The simulated monthly mean radiative effects (a change of net shortwave and longwave fluxes at the top of the atmosphere) over North America and the western Atlantic for June-July 2005 by (left) $\mathrm{LNO}_{\mathrm{x}} \mathrm{O}_{3}$ and (right) $\mathrm{ANO}_{\mathrm{x}} \mathrm{O}_{3}$. 
the monsoon is strong. The high rate of lightning flash occurrences over the region in July are also shown in the National Lightning Detection Network data (not shown). Using the in-situ observed lightning flash occurrences, the simulated lightning flashes are constrained from their dependence on MM5-simulated cloud mass flux and convective available potential energy [Choi et al., 2005, 2008b]. The impact of the $\mathrm{LNO}_{\mathrm{x}}$ on tropospheric $\mathrm{O}_{3}$ and the corresponding radiative effect are shifted eastward along the outflow regions as was the OLR [Choi et al., 2008b], resulting in large $\mathrm{LNO}_{\mathrm{x}} \mathrm{O}_{3}$-induced radiative impact (up to $0.55 \mathrm{Wm}^{-2}$ ) over southeastern US and the western North Atlantic Ocean (Figure 4). The shortwave term has similar structure to the OLR, with some increase in the outflow region.

\section{Conclusions}

[16] The impact of $\mathrm{LNO}_{\mathrm{x}}$ and $\mathrm{ANO}_{\mathrm{x}}$ on the OLR and radiative effects in June-July 2005 has been examined using the REAM simulations in conjunction with observations of the tropospheric $\mathrm{NO}_{2}$ and $\mathrm{O}_{3}$ data from $\mathrm{OMI}$ and TES, and the OLR by NOAA-16. Both OMI data and the simulations show large $\mathrm{NO}_{2}$ enhancements over northern Mexico, Texas and the southern US after the onset of NAM due to increased lightning activity. The photochemical $\mathrm{O}_{3}$ production follows in the convective outflow region. The impact of the $\mathrm{LNO}_{\mathrm{x}} \mathrm{O}_{3}$ on OLR (up to $0.35 \mathrm{Wm}^{-2}$ ) and radiative effects (up to $0.55 \mathrm{Wm}^{-2}$ ) in the convective outflow regions are up to three times as large as those from anthropogenic emissions. The simulated radiative impact in this study compares well with that $\left(0.50 \mathrm{Wm}^{-2}\right)$ over Huntsville as estimated by Cooper et al. [2007]. Despite the uncertainty in $\mathrm{LNO}_{\mathrm{x}}$ generation, the relative importance of $\mathrm{LNO}_{\mathrm{x}} \mathrm{O}_{3}$ over $\mathrm{ANO}_{\mathrm{x}} \mathrm{O}_{3}$ to the OLR and radiative impact over North America is becoming more pronounced due to the large reduction in $\mathrm{ANO}_{\mathrm{x}}$ in recent years. The radiative impact from lightning-derived upper tropospheric $\mathrm{O}_{3}$ over the convective outflow regions will be affected by the potential changes in convection due to global warming, a topic for future study.

[17] Acknowledgments. We thank all members of the OMI, TES and NOAA16 satellite team for providing the data. Special thanks to anonymous reviewers for helpful comments. This work was funded by the Jet Propulsion Laboratory at the California Institute of Technology, under contract to NASA and University of California Office of President, and Grant No. 1700-1737-322-210-13 from the Korean Ministry of Environment.

\section{References}

Bey, I., D. J. Jacob, R. M. Yantosca, J. A. Logan, B. D. Field, A. M. Fiore, Q. Li, H. Y. Liu, L. J. Mickley, and M. G. Schultz (2001), Global modeling of tropospheric chemistry with assimilated meteorology: Model description and evaluation, J. Geophys. Res., 106, 23,073-23,095, doi:10.1029/2001JD000807.

Bucsela, E., et al. (2006), Algorithm for $\mathrm{NO}_{2}$ vertical column retrieval from the Ozone Monitoring Instrument, IEEE Trans. Geosci. Remote Sens., 44, $1245-1258$.

Choi, Y., Y. Wang, T. Zeng, R. V. Martin, T. P. Kurosu, and K. Chance (2005), Evidence of lightning $\mathrm{NO}_{\mathrm{x}}$ and convective transport of pollutants in satellite observations over North America, Geophys. Res. Lett., 32, L02805, doi:10.1029/2004GL021436.

Choi, Y., Y. Wang, T. Zeng, D. Cunnold, E.-S. Yang, R. Martin, K. Chance, V. Thouret, and E. Edgerton (2008a), Springtime transitions of $\mathrm{NO}_{2}, \mathrm{CO}$, and $\mathrm{O}_{3}$ over North America: Model evaluation and analysis, J. Geophys. Res., 113, D20311, doi:10.1029/2007JD009632.

Choi, Y., Y. Wang, Q. Yang, D. Cunnold, T. Zeng, C. Shim, M. Luo, A. Eldering, E. Bucsela, and J. Gleason (2008b), Spring to summer northward migration of high $\mathrm{O} 3$ over the western North Atlantic, Geophys. Res. Lett., 35, L04818, doi:10.1029/2007GL032276.

Cooper, O. R., et al. (2007), Evidence for a recurring eastern North America upper tropospheric ozone maximum during summer, J. Geophys. Res., 112, D23304, doi:10.1029/2007JD008710.

Frost, G. J., et al. (2006), Effects of changing power plant $\mathrm{NO}_{\mathrm{x}}$ emissions on ozone in the eastern United States: Proof of concept, J. Geophys. Res., 111, D12306, doi:10.1029/2005JD006354.

Fu, Q., and K. N. Liou (1993), Parameterization of the radiative properties of cirrus clouds, J. Atmos. Sci., 50, 2008-2025, doi:10.1175/15200469(1993)050<2008:POTRPO>2.0.CO;2.

Gu, Y., J. D. Farrara, K. N. Liou, and C. R. Mechoso (2003), Parameterization of cloud/radiation processes in the UCLA general circulation model, J. Clim., 16, 3357-3370, doi:10.1175/1520-0442(2003)016< 3357:POCPIT>2.0.CO;2.

Hudman, R. C., et al. (2007), Surface and lightning sources of nitrogen oxides over the United States: Magnitudes, chemical evolution, and outflow, J. Geophys. Res., 112, D12S05, doi:10.1029/2006JD007912.

Hudman, R. C., L. T. Murray, D. J. Jacob, S. Turquety, S. Wu, D. B. Millet, M. Avery, A. H. Goldstein, and J. Holloway (2009), North American influence on tropospheric ozone and the effects of recent emission reductions: Constraints from ICARTT observations, J. Geophys. Res., 114, D07302, doi:10.1029/2008JD010126.

Kaynak, B., et al. (2008), The effect of lightning $\mathrm{NO}_{\mathrm{x}}$ production on surface ozone in the continental United States, Atmos. Chem. Phys., 8, 5151-5159.

Lacis, A. A., D. J. Wuebbles, and J. A. Logan (1990), Radiative forcing of climate by changes in the vertical distribution of ozone, J. Geophys. Res. 95, 9971-9981, doi:10.1029/JD095iD07p09971.

Li, Q., D. J. Jacob, R. Park, Y. Wang, C. L. Heald, R. Hudman, R. M. Yantosca, R. V. Martin, and M. Evans (2005), North American pollution outflow and the trapping of convectively lifted pollution by upper-level anticyclone, J. Geophys. Res., 110, D10301, doi:10.1029/2004JD005039.

Liebmann, B., and C. A. Smith (1996), Description of a complete (interpolated) outgoing longwave radiation dataset, Bull. Am. Meteorol. Soc., $77,1275-1277$

McLinden, C. A., S. C. Olsen, B. Hannegan, O. Wild, M. J. Prather, and J. Sundet (2000), Stratospheric ozone in 3-D models: A simple chemistry and the cross-tropopause flux, J. Geophys. Res., 105, 14,65314,665, doi:10.1029/2000JD900124.

Nassar, R., et al. (2008), Validation of Tropospheric Emission Spectrometer (TES) nadir ozone profiles using ozonesonde measurements, J. Geophys. Res., 113, D15S17, doi:10.1029/2007JD008819.

Osterman, G., et al. (2007), Tropospheric Emission Spectrometer TES L2 data user's guide, version 3.00, technical report, Jet Propul. Lab., Calif. Inst. of Technol., Pasadena.

Park, R. J., D. J. Jacob, B. D. Field, R. M. Yantosca, and M. Chin (2004), Natural and transboundary pollution influences on sulfate-nitrate-ammonium aerosols in the United States: Implications for policy, J. Geophys. Res., 109, D15204, doi:10.1029/2003JD004473.

Ridley, B. A., J. G. Walega, J. E. Dye, and F. E. Grahek (1994), Distributions of $\mathrm{NO}, \mathrm{NO}_{\mathrm{x}}, \mathrm{NO}_{\mathrm{y}}$, and $\mathrm{O}_{3}$ to $12 \mathrm{~km}$ altitude during the summer monsoon season over New Mexico, J. Geophys. Res., 99, 25,51925,534, doi:10.1029/94JD02210.

Schumann, U., and H. Huntrieser (2007), The global lightning-induced nitrogen oxides source, Atmos. Chem. Phys., 7, 3823-3907.

Worden, H. M., et al. (2007), Comparisons of Tropospheric Emission Spectrometer (TES) ozone profiles to ozonesonde: Methods and initial results, J. Geophys. Res., 112, D03309, doi:10.1029/2006JD007258.

Zhang, R., X. Tie, and D. W. Bond (2003), Impact of anthropogenic and natural $\mathrm{NO}_{\mathrm{x}}$ sources over the US on tropospheric chemistry, Proc. Natl. Acad. Sci. U. S. A., 100, 1505-1509, doi:10.1073/pnas.252763799.

Y. Choi, A. Eldering, and G. Osterman, Jet Propulsion Laboratory, California Institute of Technology, Pasadena, CA 91109, USA. (yunsoo. choi@jpl.nasa.gov)

Y. Gu, J. Kim, and K. N. Liou, Department of Atmospheric and Oceanic Sciences, UCLA, Los Angeles, CA 90095, USA.

Y. L. Yung, Division of Geological and Planetary Sciences, California Institute of Technology, Pasadena, CA 91125, USA. 